\title{
The Effectiveness of the Pictorial Book to Improve the Understanding of Deaf Students About Nature and Environment in Elementary School
}

\author{
Mohammad Efendi \\ Universitas Negeri Malang, Indonesia \\ E-mail: efendi.plb@gmail.com
}

\begin{abstract}
Delay in language development and communication of deaf children is a major problem for themselves and other people. Therefore, management of the education and habilitation needs to be prepared early with hoping that can increase language and communication skills through systematic learning and utilization of appropriate learning material (textbook). The purpose of this study is to describe the feasibility prototype of learning material to improve understanding about nature and the environment for deaf children in the elementary school. The results of the data analysis of this study concluded that the prototype of the pictorial book has contributed significantly to improving deaf children's understanding of nature and its surroundings, particularly, through the ability to listen and understand meaning of language, ability to read and understand the meaning of language, the ability to write and understand the meaning of language, as well as a functional knowledge of the language.
\end{abstract}

Keywords: the pictorial book, understanding, hearing impairment

Inhibition of language and speech development of children with hearing impairment become problem for themselves and others. People with hearing impairment from birth or before language and speech are formed (prelinguistic period), then the emergence of such problems since they lose the experience of hearing (Kirl et al, 2009), consequently, stunted intellectual development. Cruickshank (1980) argues that the intellectual development of a person is determined by the experience of the language, because language can be used to accept the concepts of science. For example, a child who suddenly see something new objects first found, there will be a desire to know all that is attached to the object, starting from the name, type, sound and so on (Hammil, 2004). Therefore, if someone is having a hearing impairment since birth, then the learning goals are directed so that they have the language skills were good, in terms of: (1) listening skills, (2) the speaking skills, (3) skills of reading, (4) writing skills (Tarigan, 1983; Efendi, 2008).

A child with a hearing loss since birth needs special education and habilitation management prepared early. Urgency, so that one day language barriers and communication skills acquisition due to limited ownership vocabulary minimized wherever possible (Rika, 2006). Hearing loss has negative effects on different level of reading comprehension (Sharifi, Kakojoibari, Sarmadi, 2011). Mastery of language skills and good communication of deaf children, can help them to develop the attitudes, knowledge and skills, both as individuals and community members held a reciprocal relationship with the social environment, cultural environment, the natural environment, and can develop the ability in the work or further education (Department of education, 1994). On the basis that, the main task of the teachers and parents of deaf children, in addition to developing the ability of deaf children to communicate well, more than that how a deaf child was also successful in academic and social skills (Spencer, Ertling, Marschark, 2000; Kirl et al, 2009 ).

Results of preliminary research in 2014 on the performance of teachers in teaching students in some special schools for deaf children (SDLB/SLB) in East Java (Indonesia), showing around $(52.38 \%$ ) special education teachers claimed intensive use of media images in each study. Furthermore, the quantity of the media used by teachers in the study was only able to cover $(52.38 \%)$ of the corresponding theme / topic of study designed teachers. In the interaction in the classroom learning about ( $71.43 \%)$ of teachers admitted to always use a combination of classical and individual approach, with the composition (85.71\%) tend to the individual and classical rest. Likewise the use of the method, several methods are often used in learning, including: debriefing, demonstrations, assignments, and lectures. While the reference book used as a learning resource deaf students, $(80.95 \%)$ were taken from the textbook references normal children were similar and modified. The reason is, because the reference books that are relevant to the specific needs of children with hearing impairment is very limited. Based on such exposure, this study will focus on the effectiveness of the pictorial book in accordance with the needs of deaf children in elementary school. 
Table 1. Test result summary of the pictorial book to improve language skills of deaf students in elementary school

\begin{tabular}{cccccccccc}
\hline \multirow{2}{*}{ Unit } & \multicolumn{2}{c}{$\begin{array}{c}\text { Listen \& understand } \\
\text { the meaning *) }\end{array}$} & \multicolumn{2}{c}{$\begin{array}{c}\text { Knowlwdge of } \\
\text { language **) }\end{array}$} & $\begin{array}{c}\text { Read \& understand } \\
\text { the meaning **) }\end{array}$ & $\begin{array}{c}\text { Write \& understand } \\
\text { the meaning *** }\end{array}$ \\
\cline { 2 - 10 } & Pre & Post & Pre & Post & Pre & Post & Pre & Post \\
\hline 1 & 4.33 & 11.78 & 5.66 & 10.33 & 3.44 & 6.55 & 7.44 & 9.55 \\
2 & 5.63 & 12.38 & 5.88 & 10.5 & 4.00 & 7.5 & 4.75 & 8.87 \\
3 & 3.80 & 9.60 & 4.50 & 9.60 & 2.80 & 7.30 & 4.90 & 6.28 \\
Mean & 4.59 & 11.25 & 5.35 & 10.14 & 3.41 & 7.17 & 5.70 & 8.23 \\
Conversion 0-10 & 3.28 & 8.04 & 4.46 & 8.45 & 3.41 & 7.17 & 5.70 & 8.23 \\
\hline
\end{tabular}

*) maximum score 14 poin, **) maximum score 12 poin, $* * *)$ maximum score 10 point

Table 2. Summary of the language understanding level of deaf children

\begin{tabular}{clcccc}
\hline No. & \multicolumn{1}{c}{ Indicator } & $\begin{array}{c}\text { Mean score } \\
\text { of pre test }\end{array}$ & $\begin{array}{c}\text { Mean score } \\
\text { of post test }\end{array}$ & $\begin{array}{c}\text { Equal } \\
\text { Mean score }\end{array}$ & $\%$ \\
\hline $1 \quad \begin{array}{l}\text { Listen \& understand the } \\
\text { meaning }\end{array}$ & 3.28 & 8.04 & 4.76 & 47.60 \\
$2 \quad \begin{array}{l}\text { Read \& understand the } \\
\text { meaning }\end{array}$ & 3.41 & 7.17 & 3.76 & 37.60 \\
$3 \quad \begin{array}{l}\text { Write \& understand the } \\
\text { meaning }\end{array}$ & 5.70 & 8.23 & 2.53 & 25.30 \\
4 & Knowlwdge of language & 4.46 & 8.45 & 3.99 & 39.90 \\
& $\quad$ Total mean score & 4.21 & 7.97 & 3,76 & 37,60 \\
\hline
\end{tabular}

\section{METHOD}

In accordance with a theme designed, that the purpose of this study was to analyze the media prototype utilization of the feasible pictorial book to develop the vocabulary capabilities of deaf children in elementary school (SDLB). For that reason, in the research approach was used quasi-experimental with pre-post test design (Cosby, 1985; Creswell, 2009). The subjects of this study were deaf students of class III and IV which have no other obstacles at the elementary school level in Malang and Surabaya (Indonesia) city. The data callected in this research results was grouped and analyzed using the statistical program of SPSS for windows.

\section{FINDING AND DISCUSSION}

\section{Finding}

The pictorial book with the theme of nature and the environment, before being used as an instrument of research, has been validated by a senior teacher and a special education expert from the state university of Malang. The results of learning treatments using pictorial book medium of school elementary school level in Malang and Surabaya is displayed in the tabel 1.

Based on table 1. From the above picture, it is obtained globally that language understanding capabilities of deaf children in all aspects is seen to trend growing significantly. The maximum score among indicators is different. The maximum score of indicators in listening and understanding the meaning is 14 points. The indicator of reading and understanding the meaning of language is 10 points. The indicator of writing and understanding the meaning of language is 10 points. And the indicator of the knowledge ability of functional languages is 12 points.

Based on the test results at table 2, it is known language skills of deaf children on aspects of listening skills and understand the meaning of language events before being tested with a pictorial textbook prototype. Being obtained a description of the ability to listen and understand the meaning of the story or event sample language on average about (32.28\%). After a series of tests a pictorial textbook prototype and re-evaluated, it is known that the test results of the ability to listen and 
understand the meaning of the story or event sample language the average increased to $(80.40 \%)$. Noting the figures obtained before trial and after testing of the prototype, a picture that illustrated the effectiveness of the prototype textbook can improve listening skills of deaf children around (47.60\%).

The results of statistical analysis, it can be concluded that the ability to listen and understand the meaning of the story or language events of deaf students between before and after the test was obtained $\mathrm{p}=$ $0.000(p<0.05)$, which means that there is significant influence of utilization the pictorial book in improving the understanding of deaf children.

Based on the test results of deaf children language skills in aspects of the ability to read and understand the meaning of language before being tested with a prototype of the pictorial book as listed in table 2, it was got a picture that the ability to read and understand the meaning of the language of deaf children on average about $(34.10 \%)$. After a tests series with a prototype of the pictorial book and re-evaluated, it is known that the test results of the ability to read and understand the meaning of the language of deaf children on mean score increased to $(71.70 \%)$. Noting the figures obtained before trial and after testing the prototype, a picture that illustrated the effectiveness of the prototype textbook can improve reading ability of deaf children about (37.60\%).

The results of the analysis of statistical tests, showed that the evaluation of learning outcomes of the ability to read and understand the meaning of language for deaf child before and after the trial was obtained $p$ $=0.000(\mathrm{p}<0.05)$, which means there is a significant effect of the use of the the pictorial book in improving the understanding of deaf children.

Based on the test results of language skills of deaf children on aspects of writing skills and understand the meaning of language before tested a prototype the pictorial book as listed in Table 2, a picture that the ability to write and understand the meaning of the language of deaf children about $(57.00 \%)$. After a series of tests a prototype the pictorial book and reevaluated, it is known that the test results the ability to write and understand the meaning of the language of deaf children on increased to $(82.30 \%)$. Noting the figures obtained before trial and after testing the prototype, a picture that illustrated the effectiveness of the the pictorial book can increase the ability to write and understand the meaning of the language of deaf children around (25.30).

The results of the analysis of statistical tests showed that the evaluation of learning outcomes writing skills and understand the meaning of language for deaf child before and after the trial was obtained $p$ $=0.000(\mathrm{p}<0.05)$, which means that there is significant effect of the use of the the pictorial book in improving the understanding of deaf children through writing activities ,

Based on the test results of language skills of deaf children in the functional aspects of language knowledge abilities before tested with the pictorial book prototype, as listed in Table 2. It is obtained a description that the language knowledge of functional samples around (44.60\%). After a series of tests, the prototype the pictorial book and re-evaluated, it is known that the test results of functional language knowledge abilities of deaf children on average increased to $(84.50 \%)$. Noting the figures, it is obtained from before and after testing the prototype trials, it is concluded that the effectiveness of a prototype the pictorial book capable of increasing knowledge about functional language of deaf children (39.90\%).

The results of the statistical test analysis showed that the evaluation of learning outcomes knowledge of functional language ability of deaf children before and after the trial was obtained $p=0.000(p<0.05)$, which means there is a significant effect of the use of the textbook display in improving the understanding of deaf children.

\section{Discussion}

Learning from the self-individual can be regarded as a unique and complex process, meaning that every individual who experienced a learning process have different learning styles among one another, including the involvement of physical and mental elements. Learning as an effort to make students learn (Degeng, 2000), is necessary to reorder the learning environment that enables students can learn easily (Setyasari \& Sihkabuden, 2005). For that, a good learning environment needs to provide a wide selection of flexible, including the provision of textbooks that can be easily accessed by students.

Textbook as a medium that is capable of bridging the learning process and learning has a very strategic position, especially for minimize the occurrence of verbalistic. But keep in mind to construct a textbook that can meet the needs of students is necessary to consider the technical aspects and the substantive carefully, because the textbook itself has a purpose for learning to run effectively and efficiently both in terms of time, funds, and facilities (Nasution, 2009).

According to some expert perspective, the characteristics of learning that utilizes textbooks need to pay attention to the following: (1) textbooks that must provide both information and guidelines are clear about what should be obtained learner, (2) textbooks is a means of individualized learning, so every textbook or text should be: to convince the students, to measure 
learning progress obtained, improving student learning according to their ability, as well as students focus on specific learning objectives and measurable, (3) the learning experience with a textbook provides students with opportunities for role playing, simulations and discussions in order to reach an effective learning process, (4) learning material is presented in a logical and systematic, so that students can find out when he started and when it ended the textbook, (5) any textbook have a mechanism to measure student achievement of learning objectives, primarily to provide student feedback in achieving mastery learning (Hariadi, 2011).

Based on above the description, it is assumed that a textbook can be classified in to good, if it is able to be a bridge interaction and learning effective communication. Therefore, the learning objectives of programmed competence will be achieved effectively and efficiently.

As has been mentioned in the initial assessment of this study, that the intelligence of children with hearing impairment is actually the same potential with any other normal child, but deaf children experience problems in the development of language and communication. So, tthe early indicators that appear in deaf children who are not or have not been educated among others can not be communicative and experienced in intellectual disability (Efendi, 2009). Because children with hearing impairment often have difficulty in formulating understanding, connecting, conclude, and foresee events (Somantri, 2006). On this basis the task of teachers and parents of deaf children in addition to developing the ability to communicate well is how deaf children can succeed in academic and social skills (Kirl et al, 2009).

The mastery essence of the language is as a communication tool for deaf children, since the language itself has a very strategic role which humans use to interact with the surrounding environment among others: (1) the language becomes subordinate position to make contact, (2) language can be used to express feelings, needs and desires (3) language can be used to manage and master the behavior of others, (4) language can be used to provide information (5) language can be used to acquire knowledge (Department of Education, 1994).

The loss of some or all of the ability for hear a deaf child means that the child has lost most of its life. As a result, a lot of things or events around it appears for the deaf student look like surprising, like a glass that suddenly rupture, the mother suddenly open the door without knowing the procedure (Efendi, 2009). On the basis of these conditions, the use of media learning that relevant and integrated with the language development of deaf children are expected to minimize the gaps that emerged in children with hearing impairment and normal children.
Recognizing that make deaf children learn in order to improve the understanding and use of vocabulary is not an easy job, it is necessary for specific tips. Presentations in the child's language learning factually deaf children do with deductive and inductive (Muijz \& Reynolds, 2008). Deductive presentation begins with the application of the general principle that is followed by a relevant example while deductive presentation begins with an actual example is continued towards the principle or general rules. Flexibility textbook, a medium of learning are being developed to enhance the understanding of deaf children, can be played by both presentations.

As we know that the results of the experiment of the pictorial book to some school studies was able to provide a significant contribution to the basic ability of deaf children as follows: listening skills and understand the language event, read and understand the meaning of language, write and understand the meaning of the language, as well as knowledge of functional language either in part or whole.

There are several notes behind the success of this illustrated textbook as a medium of learning for children with hearing impairment to improve the understanding of nature and the environment. Firstly, many points of the material presented in this text some of which have been simulated in everyday life through a teacher-student interaction, and among studentsparents / family, so before the start of the trial they've got enough capital means. Secondly, some students who have got good values consistently in evaluation of learning outcomes who received the intervention is education and early language development. Thirdly, there is a tendency they understand something on a "mental map" of his, consequently some sentences are arranged substantially one puts even though the child has understood the intent.

According to Chomsky, every child is able to use a language for their innate knowledge or (preexisten knowledge) that is programmed general in the brain. This knowledge as language acquisition device (LAD) does not contain the word, meaning, or the idea but simply a system that connects people (including children with hearing impairment) combines language skills (Rachmat, 2004). According to the theory of learning, children who acquire knowledge of language can go through three processes such as association, imitation and affirmation (Rachmat 2004). Association means associate an object with a particular object, imitation means imitating pronunciation listened in sentence structure, affirmation as an expression of joy is expressed when children pronounce words correctly.

Quantitatively listening research results indicate that the pictorial book is not maximized, because of the existence of a prototype textbook designed and later used as a "template" kind of textbook able to increase 
37.90 percent. Therefore, to achieve the maximum contribution required further improvement in terms of technical and substantive.

In spite of all the limitations of existing prototypes that exist in this textbook substantially and technically has become a new reference for school research. Hopefully, someday textbook become an inspiration for teachers of deaf children to design a kind of supplement teaching materials as the launch of the curriculum in 2013 (Entry for special schools implemented in 2014), which require active participation of teachers optimally, including providing various resources and teaching materials for students.

Besides that, with the establishment of the learning patterns of deaf children in elementary school for special education, later they have good language skills such as listening, speaking, writing, and reading (Tarigan, 1983). Therefore, a deaf child is able to develop the attitudes, knowledge and skills, both as individuals and make community in organizing a reciprocal relationship with the environmental, social, cultural and natural surroundings, and can develop the ability in the world of work or further education (Department of Education, 1994).

\section{CONCLUSION AND SUGGESTION}

The results of the data analysis of the trial can be concluded that the prototype of the pictorial book for deaf children in the lower classes especially for grade III \& IV at elementary school has contributed significantly to improve the understanding of deaf children to nature and its surroundings through the ability to listen and understand meaning of language $(47.60 \%)$, the ability to read and understand the meaning of language $(37.60 \%)$, the ability to write and understand the meaning of language $(25.30 \%)$, as well as a functional language knowledge (39.90\%). While the cumulative contributions textbook display in improving understanding of the language of deaf children towards nature and the environment in elementary schools outstanding amounted to $37.60 \%$.

Double effect of this research for the short and long term: (1) research has provided academic information that the format of instructional materials of any intended deaf child must always take into consideration the characteristics of children with hearing impairment as a child visual, so any format instructional materials designed to be able to be visualized, (2) in some cases these study results provide new inspiration for practitioners and academics to continue similar research with other themes, so that the theoretical and practical benefits expected to bring innovation in the education of deaf children.

\section{REFERENCES}

Cosby, P. C. (1985). Methods in behavioral research. Paulo Alto: Mayfield Publishing Company

Creswell, J.W. (2009). Research design: Qualitative \& Quantitative Approach. London: SAGE Publications.

Cruickshank, W. M. (1980). Psychology of exceptional children and youth, Englewoood: Prentice Hall.

Department of Education. (1994). Kurikulum Pendidikan Luar Biasa: Landasan, Program dan Pengembangan. Jakarta: Depdikbud.

Degeng, I. N. S. (2000). Paradigma baru penyusunan sistem pendidikan tinggi. Pidato ilmiah dalam rangka wisuda sarjana Unmer Surabaya, 1 April 2000

Efendi, M. (2009). Pengantar Psikopedagogik Anak Berkelainan. Jakarta: PT Bumi Aksara.

Efendi, M. (2008). Pengembangan media grafis bergambar berbasis komunikasi total untuk meningkatkan kemampuan bahasa anak tunarungu kelas rendah di Sekolah Dasar. Malang: Lembaga penelitian Universitas negeri Malang.

Hammil, D. (2004). What We know about correlates of reading. Exceptional children. 70(4), 453-468

Hariadi, B. (2011). Pengaruh strategi pembelajaran kooperatif tipe STAD berbasis web vs teks dan gaya belajar terhadap hasil belajar mahasiswa. Malang: Disertasi Program Pasca Sarjana UM.

Kirl, S. A., Gallagher, J. J., Coleman, M. R., Anastasiow, N. (2009). Educating Exceptional Children. New York: Hougton Mifflin Harcourt Publishong Company

Muijz, D., \& Reynolds, D. (2008). Effective Teaching. London: Sage Publication Ltd.

Nasution, S. (2009). Berbagai pendekatan dalam proses belajar dan mengajar. Jakarta: Bumi Aksara.

Rakhmat, J. (2004). Psikologi komunikasi. Bandung: PT Remaja Rosdakarya.

Rika. (2006). Pengembangan hidden card untuk meningkatkan kemampuan vocabulary bahasa Inggris siswa kelas $V$ di SDN Arjowinangun Malang. Skripsi Jurusan Teknologi Pendidikan FIP Universitas Negeri Malang.

Sharifi, A., Kakojoibari, A.A., Sarmadi, M. R., (2011). Comparison of Different Levels of Reading Comprehension between Hearing-Impaired loss and Normal Hearing Students. Audiology, 19(2):25-32.

Somantri, T. S. (2006). Psikologi anak luar biasa. Bandung : PT Refika Aditama.

Spencer, H., Ertling, C., \& Marschack, M. (2000). The deaf child in the family and at school. Mahwah, NJ: Erlbaum 
108 Journal of ICSAR; Volume 1, Number 2, July 2017: 103-108

Setyasari, P., \& Sihkabuden. (2005). Media pembelajaran. Malang: Laboratorium TEP FIP UM

Tarigan, H. G. (1983). Menyimak sebagai ketrampilan berbahasa. Bandung: Angkasa 